\title{
Kraft og Klassifikation: Frugter af Hegels Logik
}

\section{Forberedelser (Allerede)}

"le clivage demeure ${ }^{1}$

Formålet med denne artikel er at fremsætte nogle indledende overvejelser angående det at læse Glas, med særligt henblik på spalten om G. W. F. Hegel. Min første version af artiklen begyndte med at foreslå en nærlæsning af et kort afsnit af Glas, idet jeg noget vilkårligt lagde ud på side 107a/9293a og derefter forsatte så langt som muligt i forhold til den tid og plads der var til rådighed. Et indledende spørgsmål som ville vise sig at have været både en nødvendig forberedende gestus, men også en forudsætning for sit eget svar, kan fremstilles på følgende naive måde: Hvordan læser Glas de tekster den læser? Hvilken læsemåde fremviser Glas? Og allerede er vi i færd med at læse Glas. Relativt få korte passager fra Hegel (Andens Fanomenologi og Retsfilosofien - de store tekster) og fra Jean Genet bliver læst ekstremt grundigt, men disse passager (mange af de første afsnit fra Tyvens Dagbog er citeret udførligt) bliver sat i forbindelse med betydninger og momenter fundet på tværs af hver forfatters værker og i relation til andre forfattere. I Hegels tilfælde opbygges faktisk en semi-kronologisk passage igennem den venstre spalte i Glas. Men foruden disse mere eller mindre bestemte relationer forbliver utallige andre potentielle relationer ukommenterede. Specielt imellem spalterne forbliver der en ubestemt klasse af mulige forbindelser der udfordrer opfindsomheden ved umarkerede adressater. Udfordringen ville være forbundet med ikke kun at reagere på den forførende (eller frastødende) mulighed for at læse, som Glas tilsyneladende giver, men den ville også være forbundet med en bevidsthed om ansvarlighe-

1. Jacques Derrida, Glas. Fransk udgave, Paris 1974, p. 107a; Engelsk udgave, Lincoln 1986, p. 92a. Henvisninger til Glas vil i det efterfølgende være i brødteksten som: fransk udg./ engelsk udg. 
den for at undgå at skabe disse forbindelser på en for determineret facon. At læse Glas ville ikke kun være at gøre de allerede implicitte forbindelser eksplicitte. Det vil nærmere være et spørgsmål om at holde potentielle relationer potentielle (og derfor ikke som relationer). Dette problem trænger sig yderligere på så snart vi fokuserer på et aspekt af Glas der ses tydeligt på hver side, nemlig dens egen selv-fortolkning. Glas kan måske læses som en tekst der giver en fortolkning af sin egen tekst. Som vi ved, ville den eneste måde for en tekst at gøre dette på være at afvige tilstrækkeligt fra sig selv til at kunne referere til sig selv, inden for sig selv. En strategi som Glas tager i brug efter Genets eksempel: ce qui est resté d'un Rembrandt déchiré en petits carrés bien réguliers, et foutu aux chiottes, som også er delt i to, ${ }^{2}$ garanterer helt sikkert tilstrækkelig selv-afvigelse. Men vi ved også at sådanne strategier ikke er nødvendige. Ifølge en påviselig lov (loven om signaturen) ville en tekst altid være i stand til at afvige fra sig selv. Derrida har allerede formuleret denne lov i »Signature Event Context«:

»For at fungere, det vil sige: at være læselig, må en signatur have en gentagelig, iterativ, imitativ form; den må være i stand til at adskilles fra dens fremstillings nuværende og entydige hensigt. $\iota^{3}$

Denne enkle (men også dobbelte) pointe - som virker ukontroversiel i sig selv og bestemt ikke som noget nogen ville bestride - danner både grundlaget ud fra hvilket alt i Derrida udvikler sig, og fjerner samtidig dette grundlag. Det gælder naturligvis ikke kun for signaturer i den gængse betydning. Det gælder for alt der i enhver forstand kan siges at være læseligt. Denne 'gentagelighed' af formen af en signatur skaber noget af dens enestående evne til at imitere (sig selv). Men efterhånden som den bliver mere og mere genkendelig, begynder den også at afvige mere og mere fra sig selv inden for sig selv. Så Genets formulering af l'un-l'autre (der parodierer Idealistens Jeg = Jeg) fra ce qui est resté d'un Rembrandt, ifølge hvilket et utalligt udvalg af mærkværdigheder er skabt både i uafhjælpelig modsætning og alligevel med skjulte, ens identiteter, kan omformuleres ifølge denne lov om repetition (iterativitet) som har to uforenelige, men uundgåelige implikationer. Den ene yderlighed er at alt kan erstattes med alt andet. Den anden yderlighed er at alt er forskelligt fra alt andet. Et eller andet sted midt i mellem disse yderligheder er der forskellige, men genkendelige og usædvanlige tekster.

2. Jf. Glas 7b/lb.

3. Jacques Derrida: »Signature Event Context« in Limited Inc. Evanston IL 1988, p. 20. 
Hvis en tekst er usædvanlig, hvis den afviger tilstrækkeligt fra sig selv, kan den altid læses som en form for selv-fortolkning. Det ville ikke i mindre grad være tilfældet med en Hegel eller en Genet end det tydeligvis er med Glas. Så at læse Glas ville være at læse (i det mindste) det følgende: en tekst om Hegel (og Hegel om Hegel), en tekst om Genet (og Genet om Genet) og en tekst om sig selv. 'Om' i en selv-fortolkning kan måske altid (idet det fører til en af de store generelle antagelser om dekonstruktion) være 'imod.' Det første spor (begynder man at læse ved at følge spor?) involverer tre indledende sætninger. Den højre spalte i Glas begynder med en prædikativ fremstilling. Emnet er en titel, og prædikatet er opdeling: "ce qui est resté d'un Rembrandt déchiré en petits carrés bien réguliers, et foutu aux chiottes' se divise en deux. $\varkappa^{4} \mathrm{Ud}$ dsagnet beskriver Genets tekst (eller navnet på Genets tekst) som noget der deler sig i to. Det andet udsagn (næsten ikke en fremstilling, mere en form for forsiring, en afskåret bisætning, et afsnit, en sigel) relaterer muligvis til den foregående fremstilling på dets egne betingelser: »Comme le reste« (1b/7b). Det der bliver tilbage, deler sig i to - som resterne. (Den leksikalske flertydighed af ‘som’ forbliver også.) Glas fortsætter på denne kvasi-beskrivende måde: „Deux colonnes inégales, disent-ils, dont chaque - enveloppe ou gaine, incalculablement renverse, retourne, remplace, remarque, recoupe l'autre. $\|^{5}$ Udtrykkene er endnu en gang lånt fra Genets tekst idet den ene overlapper, afløser og vender op og ned på den anden ligesom Genets »enveloppes individuelles. «" Så indtil videre beskriver disse observationer hvad en tekst (eller en titel) gør (ikke hvad den betyder eller hvad den er). Men for så vidt som det er tilfældet, er det også tilfældet at disse funktioner er ligesom de der beskrives af Genets fremstilling. Genets tekst opfører sig helt enkelt på en måde som overlapper (recoupe) hans fremstillinger, for eksempel når den beskriver visionen om l'un-l'autre. Men ud over dette gælder det samme for teksten i Glas, hvis titel lige så godt kan erstatte titlen på Genets tekst ved denne lejlighed (Glas deler sig i to . . . . Som resterne). Er det for tidligt at sige at denne opdeling af sig selv (som opdelingen af sig selv mellem $i$ og for eller opdeling i sig selv) ikke vil kunne reduceres, men at det (ligesom resterne) vil forblive det singulære fokus igennem hele Glas? Er det for tidligt? Idet dette i for høj grad lyder som et retorisk spørgsmål, udgør det alligevel allerede det dilemma der vil finde os

4. "'det der bliver tilbage af en Rembrandt, revet i små ganske regelmæssige firkanter og smidt i lokummet' er delt i to«(1b/7b).

5. "To uens spalter, de taler [dobbeltsøjler - se Derridas egne kommentarer i »At kommentere Glas» i dette nummer af $K \& K]$, som hver - omslutter, uberegneligt omvender, vrangvender, afløser, kommenterer, overlapper hinanden« (1b/7b).

6. Jean Genet : „Ce qui est resté d'un Rembrandt déchiré en petits carrés bien réguliers, et foutu aux chiottes, «i Oeuvres complètes, bd. 4, Paris 1968, p. 28a. 
vekslende mellem betingelserne af to segl, déjà ('allerede') og pas encore ('ikke endnu').

Dette er hvad der bestemmer den retoriske opbygning af min egen kommentering, en prolepsis der på forhånd forsøger at forklare hvad der vil ske, dog uden forventning, for hvad der vil ske ville altid have været mellem allerede og ikke endnu, deres opdeling. Déjà vil vi lære at læse comme sigle på baggrund af strukturen af signaturens effekt som »fører min død med sig« og derfor går forud for mig. Derrida udtrykker det sådan:

»Når jeg signerer, er jeg allerede død. Jeg har knap tid til at signere førend jeg allerede er død. Jeg er nødt til at forkorte skriveriet, heraf seglet, fordi strukturen af 'signatur' begivenheden fører min død med sig en lui-même [dvs., i tilfælde af min død]. «

'Allerede' kan læses som et segl - i en tekst der er rig på segl (forkortelsestegn) - ikke mindst i hvilken glas selv har sin oprindelse, Klangen af en død udtryksmåde idet den giver genlyd hinsides krypten (men ikke endnu).

Så den foreslåede begyndelse på side 107a ville kun have været delvis vilkårlig fordi siden kan opfattes som værende i en vis forstand eksemplarisk, hvis man tager de implikationer i betragtning der også udvikles i Glas angående idealiteten af eksempler. Dette afsnit fokuserer på et punkt (eller en kraft som Hegel ville have sagt) som dialektikken ikke kan fokusere på imens den forbliver dialektisk: det fokuserer på hvad der bliver tilovers, hvad der bliver tilbage - le reste - igennem alle de passager som Hegels filosofi tager. Det vil sige at opdelingen selv forbliver fra den ene ende af passagen til den anden. Dette (passagen) er det der antyder at der måske altid kan være en anden passage - en passage à venir - men det er også det der siger at der måske ikke kan være en anden passage, for denne passage er det der allerede giver sig selv til det sidste og tanken om det sidste.

\section{At Læse Glas (107a/92a)}

"At overbevise er ufrugtbart $\aleph^{8}$

At begynde med et kneb, det store spørgsmål: Afslører Hegels Logik den inderste struktur af både det at være og det at tænke ved en gang for alle at forene resultaterne af alle tidligere filosofiske undersøgelser i ontologi og epistemologi? Om ikke andet har Hegel gjort det muligt at stille sådan et

7. Glas $26 \mathrm{~b} / 19 \mathrm{~b} ; \mathrm{JPs}$ indskud.

8. Walter Benjamin: „Für Männer« in Einbahnstraße, Frankfurt/M 1997, p.12. 
spørgsmål, selvom det ikke er klart hvordan sådan et spørgsmål kan besvares. En almindelig reaktion i den kritiske arv lader til at have været utilpashed. Denne filosofi om liv, absolut viden som absolut liv, er blevet beskrevet på mange måder, men ikke atypisk som et gravsted for de døde idéer om filosofisk historie - det sidste åndedrag af en ånd som nu er død. Denne følelse af usikkerhed hører sammen med en anden følelse og fremkalder en anden form for spørgsmål: Fører Hegels filosofi nogensinde til noget mere - er der overhovedet noget der kan blive kaldt til live igen, genoplivet, opført ud af disse nøgne knogler? Dette andet spørgsmål, der reagerer på strikturen af mistillid til logikken, til dens autoritet og dens påstande, former impulsen til en modstriktur, en indskydelse af liv imod død, hvilket selvfølgelig viser sig at være den Hegelianske indskydelse par excellence: striktur mod loven medfører død; modstriktur livet.

\section{Striktur}

Ved at undgå metasprog lokaliserer og udvikler Derrida begrebet om stricture eller striction, som kan forstås i relation til forskellige læsninger i Glas der identificerer - med det formål at overgå - konstruktionen af aflejrede metafysiske begreber og deres modsætninger. Ifølge en lov som Hegel, ved at undgå metasprog, lokaliserer og udvikler efter det tyske ord Aufhebung, fører et metafysisk begreb til dets modsætning som en selvfølge, da det kræver en yderligere operation af bestemmelse eller fuldbyrdelse som (ifølge lærebøgerne) både bevarer og ophæver det modsatte udtryk ved at satte det ind $i$ det oprindelige udtryk, men derved bliver dette udtryk også løftet til et højere plan. Det at Derrida ligesom Hegel undgår metasprog, har paradoksale effekter. Og det har indflydelse på alt hvad der vil følge her. Allerførst har Hegels undgåelse noget at gøre med hans mistillid til hvad han kalder 'fremmedheden' af filosofiske begreber: Denne fremmedartede terminologi som bliver brugt til dels på en formålsløs og til dels på en forvrænget måde, bliver et stort onde fordi den reducerer begreber som underforstået er bevagelse til noget fast og bundet, så at ånden og livet i selve indholdet forsvinder, og filosofi degenererer til en tom formalisme der meget let kan leveres som selskabelig snak; dog virker det svært og dybsindigt for de der ikke forstår terminologien. ${ }^{9}$

Risikoen for mekanisk repetition forøges i fremmedheden (eller jargonen) af filosofiske begreber. Liv og ånd står allerede på spil. Andetsteds trækker Hegel på to ærværdige eksempler som han bruger som modeller.

9. Hegel, citeret i Karl Rosenkranz: Georg Wilhelm Friedrich Hegel's Leben, Berlin 1844, p. 184 . 
Oversættelser af Bibelen og Homer til tysk tjener som inspirationer for hvad han kalder »mine aspirationer . . o om at prøve at lære filosofi at tale tysk. $«^{10}$ Hegels fremstilling af denne aspiration antyder at det filosofiske sprog ikke burde være adskilt (og ikke burde blive adskilt) fra den daglige brug af sprog på den måde som metasprog er tilbøjelige til at fungere, som om de var halvautonome fremstillingssystemer omkring andre fremstillinger, sprog som leverer udtryk der beskriver sproglige 'objekter.' Striktur kan betragtes som en ironisk revision af det Hegelianske ord Aufhebung; det er blevet adopteret fra Hegels tekst ligesom Aufhebung blev adopteret af Hegel for at lære filosofi hvordan man taler tysk. Men i adoptionen sker der nødvendigvis en adaption, en mod-striktur, ifølge hvilken et metasprog (ligesom dette) nødvendigvis dukker frem i repetitionen - ifølge Derrida, som »en oversvømmelse af sprog, af tungen som sluger sig selv og spiser sig selv, « reserven eller resterne som Hegel (og det tyske sprog) kalder Klang i modsætning til Sprache (16a/9a). I det øjeblik en forklaring er afgivet om en anden forklaring, i det øjeblik et ord tager et andet ord som sit objekt, er virkningen af selv-fortolkning, som kan være tilsigtet eller anderledes, uundgåelig. Problemet med metasprog (at det er uundgåeligt, men dog skal undgås) kan betragtes som et tilfælde af problemet omkring metafortolkning generelt.

Så den proces der er betegnet af ordet Aufhebung, kan vise sig på følgende måde: på grund af sansesikkerhedens umiddelbarhed lider bevidstheden den nød at befinde sig i modsætning til sit objekt, og den er tvunget til at internalisere dette via en reprcesentation (Hegels Vorstellung) der endeligt gør objektet begribeligt således at det bliver en egenskab ved bevidstheden selv. Den Hegelianske proces kan derfor karakteriseres ved hjælp af opdeling, internalisering og opførelse. Men når det modsatte udtryk allerede er retfærdig modsætning (hvilket den tospaltede struktur af Glas for eksempel signalerer på en tilsyneladende bogstavelig måde), så tvinges alt hvad der manifesterer ånden af enhed til at internalisere hvad der sætter sig imod det, i dette tilfælde relationen/opdelingen selv, hvilket er hvad det er relateret til/skilt fra. Det er vanskeligt at sluge en opdeling. Det er vanskeligt at

10. Briefe von und an Hegel, red. Johannes Hoffmeister, 3. udg., bd. 1, Hamburg 1969, p.100. René Descartes gør en lignende observation i sin Principia Philosophiae (1644), hvori han skriver: „Fordi vi bruger sproget, binder vi alle sammen vores begreber til de ord som vi bruger til at beskrive dem . . . . Senere finder vi det lettere at genkalde ordene end tingene; og på grund af dette er det meget sjældent at vores opfattelse af en ting er så distinkt at vi fuldstændigt kan skelne den fra vores opfattelse af de involverede ord. Næsten alle menneskers tanker er mere optagede af ord end af ting, og som et resultat af dette giver folk deres samtykke til ord som de ikke forstår, idet de tror at de engang forstod dem, eller at de har fået dem fra andre der forstod ordene korrekt« (The Philosophical Writings of Descartes, overs. John Cottingham et al., bd. 1, Cambridge, 1985, pp. 220-21). Oversættelsen af Descartes' Meditationer til fransk skulle måske også skrives ind i Hegels historie af forsøg på at få filosofien til at tale et sprog. 
repræsentere en forskellighed. Og denne vanskelighed dukker op som en form for modstriktur (contre-érection) i Glas, der konsekvent følger de drømmelignende funktioner af internaliserende repræsentation.

Derrida samler et ensemble af helt tæt forbundne betydninger for hvad han mener med bevægelsen af striktur: "greb, begrænsning, indskrænkning; det er et spørgsmål om at lukke, presse, indeholde, undertrykke, underkaste, komprimere, betvinge, reducere, tvinge, underlæge, slavebinde, indeslutte« (115a/99a). Det der er på spil her, kan midlertidigt identificeres ved hjælp af kraftens (magt, vilje, styrke, vitalitet, etc.) og klassifikationens (det at klassificere eller arrangere i klasser ifølge almindelige kendetegn eller ligheder; og derfor anvisning af noget til dets rette klasse) beslægtede anliggender. Den rytmiske striktur af repetitionerne i Glas følger det uantagelige (ufordøjelige) mønster af at foregribe repræsentation som den udvikler sig hinsides sig selv, ligesom spillet mellem frihed og død som Derrida følger i Hegels tidlige essay om »Naturlov. ${ }^{11}$ I dette essay forklarer Hegel hvordan ubetinget frihed »hæver sig over enhver modsætning eller udvendighed « ved at modsætte sig modsætningen per se. Et begrænset individ er omgivet af udvendige repræsentanter og er derfor altid udsat for risikoen for tvang. Fjernelsen af denne modsætning ville være ubetinget frihed. Så hvis både individets $o g$ dets modsætnings bestemthed bliver fjernet, så »er det begrænset [bezwungen], men ikke tvunget [gezwungen]. $\|^{12}$ Modstrikturens grundsætning, begrænsningen af tvang som ikke er tvang, er død: »denne totale frihed viser sig som død, og gennem sin evne til at dø beviser subjektet at han er fri og fuldstændig hævet over al tvang." 'Ordspillet' (bezwungen, men ikke gezwungen) viser Hegels beslutning om at opdele ordet Zwang for at løfte det via bezwingens rejsning til døden. Denne "absolutte forøgelse af en contre-érection« skal være stærkere, skal overgå ethvert udtryk for kræfters empiriske eller naturlige modstand, og skal derfor være forbundet med det at gå udover empiriske beregninger. Den absolutte forøgelse ville repræsentere en 'naturlig' død, men et 'åndeligt' liv, allerede ifølge en lov som Hegel vil komme til at referere til, for eksempel i Logikken, som den

11. Glas 114a-17a/99a-102a; Hegel: „On the Scientific Ways of Treating Natural Law, on its Place in Practical Philosophy, and its Relation to the Positive Sciences of Right (1802-03), « i Political Writings, overs. H. B. Nisbet, red. Laurence Dickey og H. B. Nisbet, Cambridge 1999, pp. 102-80. Dette meget vigtige tidlige essay af Hegel indeholder hans mest vedholdende og sammenhængende udgave af den notoriske kritik af det Kantianske moralbegreb, og derfor indtager Hegels essay en afgørende plads i Derridas læsninger i Glas idet de først og fremmest viser at Hegels hensigt med at fastlægge en spekulativ opfattelse af Sittlichkeit, på en og samme gang involverer kritikken af empirisme og formalisme (Hegel tager familien som et kortfattet eksempel på den måde som empiristiske og formalistiske redegørelser forudsætter uantagelige bestemmelser).

12. "On the Scientific Ways of Treating Natural Law, p.138. 
omvendte verden: »Relationen er . . . at verden i og for sig er det omvendte [die verkehrte] af en verden af tilsynekomst. ${ }^{13}$

\section{Døden}

Det lader til at døden ville være det eneste middel til at »beregne det uberegnelige« (115a/100a). Men døden forbliver uberegnelig. Ingen relation eller overensstemmelse kan beregnes mellem ubetinget frihed (døden) og begrænsede/endelige kræfter (livet): »ingen bestemmelig lighed, ingen bestemmelig kommensurabilitet, ingen bestemmelig analogi lader sig forstå mellem deres to protokoller, deres to rækkevidder [portées] (116a/101a). Denne »ingen relation" (senere vil vi forbinde det med 'ikke dér' [not there] af en a priori relationsmulighed per se) mellem de to rækkevidder (deux portées) kan midlertidigt stilles op ved siden af en række andre former for ingen relation, til at begynde med den vedrørende gaven som i nogen grad er tematiseret i Glas, selvom effekterne deraf er læselige hele vejen igennem. $\mathrm{Vi}$ ville læse den følgende fremstilling som en bekræftelse: "Aucun rapport ne s'y donne à entendre, ne donne prise aux concepts finis et aux déterminations de l'entendement." Ingen relation giver sig selv til forståelsen og til finitte bestemmelser (ibid.). Her danner det ubestemmelige, det uberegnelige, det umulige, gaven (idiomet se donner la mort, oversat med 'at tage sit liv,' følger en inversion som er muliggjort af hvad Derrida kalder »den store lov om Gift-gift $«^{14}$ ) en række metonymiske udtryk for hvad der giver sig selv til bestemmelse gennem en vedvarende ubestemt rytmisk kraft (hvilket for eksempel er signaleret med den tospaltede struktur af Glas som tilsyneladende fremsætter sig selv som analogiserende, som her, hvor den højre portée følger tråden i rollen af fil eller fils gennem en række metonymiske forskydninger som inkluderer vigilien, jomfruen og døden). Lidt senere vil vi erfare at denne utilstrækkelighed mellem det begrænsede og ubegrænsede svarer til individets mislykkede bestræbelse på at leve op til sin universelle slægt (i.e., individuelle totaliteter uddør mens deres klasse forbliver). Så »døden er individets utilstrækkelighed i almindelighed; det er klassifikation i sig selv; livets ulighed med sig selv. «" ${ }^{15}$ Punktet hvor klassifikation ikke kan klassificeres (og hvor abstraktion ikke kan abstraheres), ville være punktet, momentet, magten eller kraften af klassifikation i sig selv. Hegels forsøg på

13. Hegel: Werke, red. Eva Moldenhauer og Karl Markus Michel, bd. 6, Frankfurt/M 1969, p.161.

14. "Cette inversion relève de la grande loi du Gift-gift $«$, Jacques Derrida : Donner le temps. Paris 1991, p.77; jf. La dissémination. Paris 1972, p.150. Glas vender tilbage i Donner le temps, eksplicit i de fire versioner af Mallarmés »Aumône« (pp. 78-80). Jeg står i gæld til et igangværende arbejde af Chrissie Tan S. E. Phillips omkring behandlingen af døden i Derridas værker. 
at mestre dette punkt leder ham til at bekræfte (blandt andet) dødsdommen, de foryngende effekter af krig på et etisk samfund, og en Gud der frembringer sig selv ved at undgå seksuelle relationer.

\section{Hvad der forbliver i oversættelsen}

Idet vi forbinder oversættelse med død, vil vi være berettiget til at konkludere at ikke meget bliver tilbage af Hegel. Mange engelsk talende, for eksempel, ville have lært af William Wallace eller J. N. Findlay at kun et livsvarigt studium kan bringe den Hegelianske student til en bevidsthed om Hegels ånd og hans tankegang; og vi lærer også hurtigt at sætte lighedstegn mellem denne tankegang og filosoffens eget levende åndedrag - sørgeligt bortgået, men måske bedst fanget af de ofte usikre, men oprindeligt mundtlige bemærkninger eller tilføjelser til forelæsningerne - die Zusätze. Og i Findlays indledning til Logikken (Wallaces oversættelse af Logikken fra Encyklopedien) bliver vi tilskyndet til at acceptere, at mens Wallace (idet han bruger de tilfældige registre over både engelsk i slutningen af det 19. århundrede og sit eget særlige formsprog) i bedste fald kun giver en omtrentlig version, som ikke desto mindre er det bedste vi kan håbe på, endog bedre, formoder vi, end hvad de tyske udgaver leverer (hvilket ikke ville være meget mere end de tomme afskrifter af Hegels håndskrift der venter på at en eller anden oplyst ånd vil bringe dem til live) så tilbyder Wallace en distinktiv og indsigtsfuld skønt, indrømmet, excentrisk fortolkning. ${ }^{16}$

Oversættelse er derfor ikke et problem kun for ikke-tysk læsende - de tyske tekster er selv oversættelser, inskriptioner af Hegels ånd - eller udtrykt på hans egen specielle måde: forberedelser (oversættelsen oversætter en forberedelse). Det er det som vi alle vegne opfordres til at forstå om Hegel: hans værker er en lærers værker; hans værker er fundamentalt forberedende. Det Hegelianske ord - Voraussetzung, 'forudsætning'; Derrida foreslår pro-thèse ('tilføjelse') - beskriver et moment eller en magt, magten af pro, som fra de allerførste værker til de sidste betegner hvordan filosofien på sin egen ordentlige måde kommer til at være sig selv (110-11a/96-97a). En komplika-

15. Glas 133a/116a. Både i Logikken og i Encyklopcedien gives klare redegørelser for livets og dødens dialektik, slægtens rolle (die Gattung) i understøttelsen af det naturlige [biologiske] liv og forholdet til og rollen af parring. Dette er fra Logikken: "I parringen [Begattung] forsvinder umiddelbarheden af den levende individualitet; dette livs død er fremkomsten [Hervorgehen] af ånd«, Werke, bd. 6, Frankfurt/M 1969, p.486.

16. I de indledende bemærkninger til et meget senere samarbejde, The Encyclopaedia Logic, Indianapolis 1991, påpeger W. A. Suchting at man ikke skal stole på Wallace: »Den der sammenligner hans version med den tyske, må ofte være fristet til at sige ' $C$ 'est magnifique, mais ce n'est pas Hegel'" (p. xiv). At læse Wallaces engelske overfor Hegels tyske kan give os anledning til at sige det samme. 
tion kommer til syne ifølge hvilken filosofien befinder sig i hvad der endnu ikke er filosofi, og kombinerer og forbinder således betydninger, der logisk trækker sig væk fra hinanden, i dette tilfælde de to betydninger af déjà ('allerede') og pas encore ('ikke endnu').

\section{Tabte Begyndelser}

Når man følger sporet fra de skrevne eller oversatte rester af Hegel tilbage til tanken, er der intet andet sted at gå (hvad bliver tilbage af Hegels ånd?). Hvis filosofien skal træde frem fra det der endnu ikke er, men allerede [er] filosofi, må vi finde tilføjelsen, den filosofiske sætning i selve Hegels filosofi. Det er denne slags formulering (»filosofi skal«, »Hegel skal«, "vi må») som Derrida fokuserer på som filosofiens behov (le besoin de philosophie). (110a/96a.) Filosofiens behov er at blive placeret i de dele af filosofien som mere end andre dele endnu ikke er filosofi, så vi kan se den opstå i sin rette bevægelse, bevægelsen af pro. Ved at følge Hegels filosofi tilbage til før dens opblomstring (men hvilken del af Hegel er mere 'ikke endnu' end nogen anden?) skulle vi kunne følge dens opståen idet den passerer fra hvad den ikke er endnu, til hvad de bliver - følge den tilbage for at følge den videre $\mathrm{i}$ dens tilblivelse. Så skal vi gå tilbage til begyndelsen - de første eksisterende værker? ${ }^{17}$ At gøre dette ville ikke være så filosofisk som Derrida påpeger i en fremstilling af metoder: »Nous ne pouvons pas feindre de commencer par le commencement chronologique« (1la/5a). Vi kan ikke foregive at begynde ved den kronologiske begyndelse. Foreløbig striktur, tilføjet begrænsning: Hvad begrænser os her?

1. Vi kan ikke fortolke slutningen (dvs., den svære modne filosofi) uden at spore dens opståen.

2. Vi kan ikke begynde ved begyndelsen uden at se hen til overgangen til slutningen.

3. Men vi kan ikke undgå passagen fra begyndelse til slutning som teleologisk foregriben.

Det der begrænser os, er det der interesserer os (ibid.).

17. Eller før skrifterne kan vi rekonstruere Hegels tidlige liv med hjælp fra talrige filosofiske/ biografiske fortolkninger. For eksempel viser H. S. Harris os i sin fortrinlige Hegel's Development: Toward the Sunlight, 1770-1801, Oxford 1972, en eksemplarisk Platoniker, Hegel, der træder ud fra hulen. 


\section{Gentagelig Ånd}

Passagen mellem begyndelse og slutning udgør et rum - ikke synligt som sådan, men ikke desto mindre et rum - hvis essens (Wesen) måske kan skimtes imellem denne række af udtryk: spaltning, adsplittelse, splittelse, adskillelse, opdeling, brud, krænkelse/sår, opløsning, deling, etc. Udtrykkene i denne række (principielt er den uendelig) indikerer et tilsyneladende behov over for hvilket fornuftens magt opstår som en reaktion - forening, syntese, analogi, begreb, forbindelse (copula), fuldbyrdelse, fortæring, etc. Men dette er kun fornuft som en af forståelsens kategorier. Forståelsen identificerer modsætninger på en måde som efterligner fornuftens magt (skaber en død fornuft i sin repetition). Fornuft river sig løs fra sin døde form, kategori af forståelse, og må derfor nu tonke denne nye opdeling (gentagelsen) - forstå den i en yderligere bevægelse af endeløs forening/opdeling (til trods for vægten på det absolutte i logik - slutningen). Ifølge dette bevægelsesmønster er det umuligt at skelne mellem fornuftens kraft (denne foreningens kraft) og en generel gentagelighed hvis lov samtidigt skaber loven (gentagelser af det samme) så vel som behovet for filosofi: opdeling, adsplittelse, spaltning, adskillelse, etc., forskellen i gentagelsen af det samme fra sig selv. Navnet som Hegel giver denne lov, er Aufhebung, og Derrida forklarer det sådan: „Elle est l'histoire, le devenir de sa propre présentation, de sa propre détermination différenciante, et elle est soumise à la loi, à la même loi que ce dont elle est la loi. ${ }^{18}$ Aufhebung er historie. Det er hverken en bestemt ting eller en formel abstrakt strukturel regel som bestemmer hvert moment (det er hverken væren eller begreb). Det er snarere tilblivelsen af dets egen differentierende bestemmelse og er derfor også underlagt loven for (dets egen) differentierende bestemmelse. Det er underlagt den samme lov som alt andet det er lov for. På den samme måde (iterum - derechef - ligeledes) er loven for repetition selv underlagt lovens gentagelighed, uden hvilken loven ikke ville bestemme noget som helst. Det ville være denne gentagelighed af loven - imod hvilken ånden gør oprør som liv imod død - som ikke desto mindre holder ånden i live i dets differentierende bestemmelse.

Passagen mellem begyndelse og slutning skal tænkes som teleologisk forsætlighed, men så kun inden for en generaliseret gentagelighed der samtidig undergraver den teleologiske styring ifølge dets lov og betingelse. Hvad betyder dette praktisk set? Loven har indflydelse på vores ansvarlighed over-

18. "Aufhebung er historie, tilblivelsen af sin egen sande præsentation, af sin egen differentierende determinering, og den underlagt loven, den samme lov som den, den er lov for.« (139a/12la). 
for hvad der samtidig interesserer og begrænser os i Hegels tekst. Det et derfor at Hegel ikke bare kunne, som en vis analytisk tradition aldrig er blevet træt af at forlange, sige hvad han vil have os til at vide. Filosofiens før-position (pro-position) er endnu ikke den filosofiske sætning. Igen har Derrida givet os formlen: »Vi kan hverken undgå eller acceptere teleologisk foregribelse som regel eller princip, hverken acceptere eller undgå den empiriskkronologiske forsinkelse af récit som regel eller princip« (12a/6a). Som vi lige har set, falder en vis lov - Hegels Aufhebung - selve den filosofiske sætning som vi forbereder os til at læse, ind under den samme lov (og er loven) som bestemmer hvad vi nu kan begynde at udfolde som loven (altid gemt) der bestemmer det at læse generelt. Dette er hvad der har indflydelse på vores ansvarlighed:

1.Vi skal stræbe efter at påtage os og afdække den litterære menings ånd [the spirit of the letter] i Hegels tekst. Vi skal arbejde på at forstå, at begribe og at fuldende opdelingen/relationen mellem vores læsning og hans tekst.

2.Men for at blive ved med at være helt tro mod den litterære mening i Hegels tekst, og derfor mod ånden, skal vi følge betingelserne af loven selv, underkaste os loven og loven der bestemmer loven, hvilket samtidig er at løsrive os fra loven i dens tomme og døde repetition. Ånden må komme til syne igen i kløften mellem hensigt (eller slutning) og forsinkelse, som når alt kommer til alt udgør muligheden for læsningen og derfor har direkte indflydelse på vores ansvarlighed og frihed.

Man må forberede sig på at læse Hegel ved at læse Hegel. Hvad der begrænser og interesserer os, viser sig i Hegel at være netop den ting som har indflydelse på vanskeligheden af at læse Hegel. Begrænsningen - begrænsning i sig selv - er hvad der interesserer os. Begrænsning i sig selv - for eksempel i de samtidige betydninger af déjà og pas encore - begrænser os til en fortolkning der er ude af stand til at begynde enten ved slutningen (og således indtræffe for hurtigt) eller ved begyndelsen og falder langt fra slutningen, for langt til nogen sinde at udgøre opdelingens afstand. Vi må begynde med hvad der allerede er filosofi (striktur), men endnu ikke er filosofi (modstriktur). Omsat til problemet med at læse befinder vi os mere eller mindre nøjagtigt i den samme position som Hegel når han i de tidlige værker, for eksempel, reagerer på den kristne religion som den opstår ud fra den jødiske tilslutning til døde mekaniske love og derpå reagerer på Kants etik (den stjerneklare himmel ovenover og den moralske lov inden i, eller Naturlovene og fornuftens praktiske vilje) der balancerer mellem må og kan og ønsker forening mellem alle udtrykkene for forskellen på nødvendighed og frihed. 
Derridas kommentarer om Hegel svinger mellem to udtrykstyper: udtryk i retningen "Hegel må . . « og udtryk i retningen "Hegel vælger.» Mellem disse bestemmelser (de der adlyder loven, og de der afgør) finder vi Glas' passage. Betyder det at vi skal begynde med passagen? Når man undlader at begynde ved begyndelsen (hvilken begyndelse?): »Je commence par l'amour.« Jeg begynder med kærlighed (12a/6a).

\section{Kærlighed}

Om ikke helt begyndelsen, så menes fragmentet Kcerlighed dog at være skrevet sidst i 1797 (efter Jesu Levned, men før Kristendommens And). Fragmentet begynder midt i en sætning, og ingen har endnu kunnet redegøre tilstrækkeligt for hverken meningen med det første afsnit eller for dets forbindelse med resten af fragmentet. Udgivne versioner af de eksisterende rester leverer spekulative forsøg på en rekonstruktion på en måde der er karakteristisk for næsten alle udgaver af Hegels værker fra den periode, men de lægger kun vægt på den generelle usikkerhed om hvordan disse fragmentariske begyndelser burde fortolkes. Sådan er det ikke med hovedparten af fragmentet i hvilken det, der allerede er et karakteristisk Hegeliansk argument, folder sig ud: kærlighed er enheden af modsætningers der overvinder deres modsætning og realiserer sig selv i barnet, som så i sin egen udvikling modsætter sig selv for at blive forældrene. Kærlighed (ikke endnu filosofi) udfører allerede filosofiens arbejde, reagerer på det behov som filosofi reagerer på. Kærlighed, filosofiens tilføjelse, er udviklet i de første værker som relationen mellem Kant og Jesus. Grækerne er endnu ikke kommet ind i billedet. Vi er stadig i forgården (»avant-cour, "Vorhof) til filosofiens kirke. ${ }^{19}$ Hvor skal vi lede efter barnet?

\section{Jesu Liv}

Vi kunne være fristet når, vi læser de første værker, til at finde en model eller et sidestykke til filosofiens behov i jødernes situation da Jesus kommer ind i billedet: "Af ånd blev intet tilbage undtagen stædig hovmod over slavisk lydighed mod love der ikke blev skabt af dem selv. $\mathbb{1}^{20}$ Denne lydighed mod fremmede love viser en »livløs, fortabt og mekanisk tilbedelse« og kræver et

19. Glas 110a/96a. Denne Vorhof (og dets figurative slægtninge Voraussetzung, Vorbegriff, Vorstellung, Hervorgehen) er som en slags forgård eller plads der er en del af Kirken, men som ikke i egentlig forstand er i Kirken. Derrida trækker på forestillingen om parvis, hvilket er en slags scene hvorpå diskussioner, dramaer (langfredags- og genopstandelsesstykker, for eksempel) etc., finder sted (ligesom på den der er foran Notre-Dame).

20. Hegel: Early Theological Writings. Oversat af T. M. Knox, Chicago 1948, p.178. 
forenende princip på grund af deres »hovmodige og fjendtlige adskillelse fra alle andre folk. $\aleph^{21}$ Modsætning og livløs repetition ${ }^{22}$ skaber et behov for forening $o g$ frihed fra lovens yderlighed (her sætter to modsætninger først jøderne op imod alle andre og derefter lovens ydre form - eller slaveri - op imod den indre form af friheden). Behovet appellerer derfor til en kraft der ville befri (relever) disse modsætningers betingelser - en forenende kraft (Macht der Vereinigung). Når intet bliver tilbage af ånden, bliver ånden interesseret og reagerer idet den er begrænset af dette behov. Allerede her (er dette et tidligt allerede der venter på at blive afløst af en senere modning, eller er det allerede den filosofiske sætnings allerede og ikke endnu?) vækker en komplikation vores interesse og indskrænker vores reaktion.

\section{At Læse (Ikke Endnu)}

"le clivage demeure $\aleph^{23}$

Spaltningen forbliver. Vi begynder med side 107, venstre spalte. En afstand mellem to afsnit repræsenterer en passage mellem den foregående passage, et langt stykke om den kristne religion, og den følgende passage: et afsnit om politik. Sagen er altså denne: i midten af passagen fra religion til filosofi passerer vi gennem passagen fra det åndelige til det politiske. Hvordan er passagen opnået, udført? Passagen mellem passager deler to opdelinger, spalter sig mellem to spaltninger, splitter to adsplittelser. Idet vi således sætter skarpere fokus på et eksemplarisk moment, et tilfælde af denne i princippet ubegrænsede række, men bliver fanget i de flossede kanter af en splittelse der er strengt (nu ifølge en uantagelig striktur) umulig - et eksemplarisk moment der ikke kan klassificeres - fokuserer vi (og ikke for første gang) på

21. Op.cit., p.179.

22. Hegel udtrykker sin interesse i Jesu egen modning - et spørgsmål der forbliver ubesvaret. Vi ved intet om den tidlige udvikling af Jesu liv. Han lader til at være dukket op i en allerede færdig skikkelse eller i midten af en sætning, allerede fri af den jødiske mentalitet: "Angående det interessante spørgsmål omkring hvordan Jesus modnedes, har vi ikke fået overleveret nogen som helst information. Det er i sin manddom at han først viser sig, og på det tidspunkt var han fri af den jødiske mentalitet, fri af den hæmmede inerti der bruger sin ene aktivitet på livets bekvemmeligheder og almindelige behov, også fri af ambitionen og andre lidenskaber hvis tilfredsstillelse ville have tvunget ham til at acceptere fordomme og laster" (Early Theological Writings, p.179). Ikke desto mindre virker denne skikkelse i Hegels spekulative rekonstruktion i mindre grad end i den endnu tidligere Das Leben Jesu (1795) som en fuldt udviklet Kantianer, en slags legemliggørelse af den praktiske vilje. I Das Leben Jesu prædiker Jesus morallov i Bjergprædikenen og siger: "Handl efter den grundsætning som du samtidig ønsker skal være en universel lov« (in Gesammelte Werke, red. Friedhelm Nicolin og Gisela Schüler, bd. 1, Hamburg 1989, p.221). Efter dette bliver Kant selvfølgelig degraderet af Hegel til kun at være jøde.

23. Glas 107a/92a. 
et moment (magt, kraft) der spiller en fundamental rolle i systemet. Forholdene i afsnittet der går forud for splittelsen, er betydningsfulde: i Hegels récit erklærer Jesus krig imod jøderne i forsoningens navn, men valger (udvælger, beslutter sig for) en yderligere adsplittelse der synes at gentage eller fastholde nøjagtig den samme spaltning som hans tilsynekomst i begrænset form skulle forene. Ved at vælge døden ofrer han sin jordiske tilstedeværelse (ofrer han den guddommelige tilstedeværelse på jorden) til fordel for ubegrænset forening med den ubegrænsede Fader. Han skaber med andre ord et fravær. Det guddommeliges fravær som Jesus selv vælger for sit folk, skaber yderligere ødelæggelse: »flugten ud i tomrummet skaber grusomhed og ødelæggelse.»(106a/92a.) Jesus vælger sin egen død - ulykkeligt og ikke vanvittigt eller fantaserende, for han gør det for et folks skæbne snarere end for sig selv - i forsoningens, kærlighedens og foreningens navn. I dette tilfælde er valget han træffer, i overensstemmelse med hans skæbne som (værende) den kristne religions skæbne: »Ved at knække over i to og ved at flygte har han erklæret krig i forsoningens navn. Han er splittet i sin egen egentlige splittelse, forhærdet overfor selve splittelsen idet han mangfoldiggør den og derfor opløfter den til uendelighed.«(107a/93a.) Jesus kommer til verden splittet overfor splittelsen kun for at splitte sig selv og gentager splittelsen som han splittede sig selv overfor (derfor til uendelighed). Spaltningen forbliver.

Denne splittelse som identificerer det ubegrænsede med guddommelig nødvendighed og sætter det op imod det begrænsede og jordisk tilfældighed, er allerede (men ikke endnu) filosofi for så vidt som den allerede skitserer den strukturelle splittelse der i sin mest abstrakte form udgør filosofiens behov. Ved at tage en begrænset og empirisk form ville Jesus allerede i princippet have forenet det guddommelige med den tilfældige verden. Men hans forsvinden ud i tomrummet efterlader et fravær der gentager den oprindelige splittelse, dog mere kraftigt, og derfor invaderer hans ledsageres verden, hans ledsagere der bliver tilbage for at bygge hans kirke.

Effekterne af denne splittelse (»Denne splittelse har effekter hvis politiske analyse næsten ikke engang er [på]begyndt« (op.cit.); vi er stadig i de tidlige værker og bevæger os nu videre til de politiske værker fra 1798-1807) passerer fra det religiøse til det politiske ifølge visse begrebsmassige kendetegn (»elles sont conceptuellement marquées" (108a/93a)) der foregriber de senere og derfor mere udviklede politiske og filosofiske værker. Her dukker familiens plads op som uantagelig, men fundamental. Den er fundamental som kilden til det grundlæggende forhold der skal fuldendes (og forbruges) af fællesskabets etiske relationer. Den er uantagelig fordi Hegels treenige figur (Forældre og barn) aldrig finder et bestemmeligt midtpunkt for de relationer og udvekslinger der finder sted i deres navn. Der er altid noget der 
er tilføjet (søstre, brødre, onkler, tanter), noget der mangler (fædre, mødre, børn, osv.) eller noget der er brudt. Den hellige familie tjener som et billede på splittelsen. Forskellen på den almægtige/uendelige Fader og jomfru Maria definerer mere eller mindre den transcendental-empiriske forskels arvede form der bliver filosofiens egen egentlige splittelse (og behov). Sønnens skikkelse og hans splittelse mellem åndelig og verdslig handling repræsenterer et skisma der skal overvindes. Så familien er et af navnene på tilføjelsen som filosofien gentager og sætter i stedet for sig selv. Fornuften ville derfor være Hegels navn for den kraft der kan forene det der tidligere forblev adskilt. Adskillelsen er givet mellem absolut objektivitet (nødvendighed, stof, krop, forståelse, følelse og natur) og absolut subjektivitet (frihed, ånd, sjæl, tro, fornuft, forstand).

\section{Familie}

Hvis vi går tilbage til strikturen af déjà og pas encore og til Aufhebung som værende undergivet den samme lov som det, det er lov for, kan vi nu bestemme det rette sted for familien ret præcist. Det kan ikke lokaliseres. Splittelsen imellem (som den egentlige adsplittelse af kristendommen) forbliver gennem passagen mellem kristendommen og filosofien således at splittelsen indenfor kristendommen passerer over i eller bliver til filosofiens behov (eller splittelsen der er kristendommen, er allerede og ikke endnu splittelsen som er behovet for filosofi). Passagen eller splittelsen imellem splittelsen i kristendommen og filosofiens splittelse eller behov er overensstemmende med passagen fra familie-syllogismen til syllogismen i det borgerlige samfund. Med andre ord er splittelsen mellem kristendommen og filosofien overensstemmende med splittelsen mellem familie og samfund. Hvilket vil sige at opløsningen af kristendommen og opførelsen af filosofi ud af dens aske svarer til opløsningen af familien. Tilsynekomsten her af denne præcise, men vanskelige analogiske relation påtvinger en ny splittelse - Derrida lader det være på dette stadium »en plant. ${ }^{24}$ Men det er værd at lægge mærke til formen som den antager: »Nu har denne endelige splittelse mellem tilstedeværelse og repræsentation, mellem for sig selv og i sig selv, formen af en ulighed mellem faderen og moderen i relationen til faderen og relationen til moderen. Passagen fra absolut religion til $S a$ forbereder sig [se prépare] som denne uligheds relève. ${ }^{25}$ Kilden til denne formulering er selvfølgelig Jesu skikkelse, hvis relation til Faderen, et ubegrænset potentiale, ikke er lig hans relation til moderen, som kun er virkelig. Så uligheden der former den

24. "Son en kimplante« (109a/94a).

25. 108-09a/94a. Husk endvidere at $S a=$ savoir absolu, 'Absolut Viden' 
fundamentale splittelse mellem ubegrænset potentiale og begrænset virkelighed, må gøres lige for at få passage til fællesskabet. Det vil sige at ubegrænset potentiale skal virkeliggøres. $S a$ ville være denne slutning. Præcis som Jesus har en relation til faderen $i$ (sig) selv (ansichseienden Vater) og kun en virkelig moder, så har fællesskabet også et forhold til hvad det er i sig selv (sin egen rette funktion) og en relation til moderen som er karakteriseret ved »en evig kærlighed, som det føler, men det ikke anskuer i sin bevidsthed som en virkelig umiddelbar genstand. ${ }^{26}$ Som Derrida påpeger her, er det for tidligt (»Il est trop tôt«) at læse denne passage (109a/94a).

Hvad betyder det når man siger at det er for tidligt at læse denne passage? Hvis det er et spørgsmål om at følge den empiriske kronologiske passage i Hegels værker der begynder et sted nær ved den (tabte) begyndelse og fortsætter fremad, så kommer denne passage hen imod slutningen af Andens Fænomenologi (slutningen af det næstsidste kapitel der foregriber det sidste), og vi er stadig ved opdelingen mellem de første religiøse og politiske værker. Analogien her er kun et lille frø der foregriber sin fremtidige opspringning. Alligevel kan den kronologiske striktur, som vi har set, kun opretholdes ved siden af en modstriktur ifølge hvilken vi hverken kan acceptere eller undgå forsinkelsen af Hegels teleologiske udvikling. Og her dukker endnu en komplikation op. Forsinkelsen (ikke endnu, for tidligt) kan fremstå (specielt i dens uenighed med déjà) som om den rejser et spørgsmål om det rette hvornår for denne passages rette tid. Når vi vender tilbage til det 140 sider senere, vil dette spørgsmål om hvornår være udelukket og afslører derfor at det for tidlige ved dets tidligere optræden drejer sig mere om den tid en læsning (ligesom en religion, ligesom filosofi) behøver end det drejer sig om den rette tid til at læse det. Før vi når til repetitionen af citatet, udfører Glas en alvorlig komplikation af formen og betydningen af déjà og pas encore: "Absolut religion er endnu ikke hvad det allerede er: $S a$, hvilket i udfoldet tilstand lyder som følger: "'allerede-der' af 'ikke-endnu', 'allerede' mere end 'endnu' kan ikke høres«. (»Le déja-là du pas-encore, le déjà-plus de l'encore ne peuvent pas s'entendre« (244a/218a).) Kompleksiteten af syntaksen matcher kompleksiteten af uoverensstemmelsens mulige betydninger. Først er uoverensstemmelsen måske kun gentagelsen af splittelsen selv, mellem fornuft og forståelsen, mellem det guddommelige og det formelle, mellem potentiel og det kun virkelige (Faderen og jomfru Maria). Uoverensstemmelsen ville derfor udgøre filosofiens behov, i formen af hvad det endnu ikke er, men allerede (i princippet) er. Eller også »beskriver« det absolutte 'allerede-der' af 'ikke-endnu' eller det absolutte 'allerede' ikke

26. Hegel: Andens Fanomenologi. Oversat af Claus Bratt Østergaard, København 2005, p.548; Phänomenologie des Geistes in Werke, bd. 3, Frankfurt/M 1970, p.574. 
mere af 'endnu' »en evig eller utemporal cyklus« (loc.cit.); de beskriver hvad der ikke viser sig i empirisk eller formel tid, i stemmens eller forståelsens tid. Hvilket tilfælde der end gør sig gældende, så kan kompleksiteten af syntaksen også reduceres til en mere simpel formulering, pas-là - 'ikke der'. Med andre ord kan alt hvad der er betegnet af passagen: splittelsen, opdelingen, osv., simplificeres som et 'ikke der' (hvad enten det ikke 'endnu' er der - og derfor endnu er i sin vorden - eller 'allerede' er der, men er andetsteds og derfor 'allerede' ikke længere er 'der'). Når formuleringen henfalder til tiden, betegner dette 'ikke der' en fremtid hvis fortid aldrig var nogens nutid. Kort sagt falder spørgsmålet nu på værdien af 'tilstedeværelsen’ i sig selv, spørgsmålet om her, nu, og om hvorvidt nogen form for 'her, nu' nogensinde bare er her, nu (igen bliver et problem ved at læse Hegel, om end kun via metonymisk forskydning, et problem ved at læse generelt).

I og med at Hegels næste sætning bliver indbefattet i Derridas repetition af Hegels passage om passagen, bliver det 'for tidlige' afsløret i sin funktion som en rest (endnu, stadig, rester): "»Sa réconciliation est donc dans son Coeur mais encore scindée (noch entzweit) et son effectivité encore brisée (noch gebrochen). « $\ll^{27}$ Dets forsoning er derfor fundamental, men er stadig uenig med dets bevidsthed (spaltningen forbliver), og dets virkelighed er stadig brudt. Forvandlingen af familie relationen er forbundet med en beslutning om (Hegel vælger) at skære hvad der forbliver uantageligt i systemet, væk (vi har foreløbigt identificeret dette som filosofiens behov i dets egentlige splittelse og generaliseret det som hvad der 'ikke' er 'der') ved at fortrænge det - ved at bringe sønnen og faderen til enighed som et fællesskab og udelukke moderen som et ubevidst kvasi-transcendentalt objekt: hun beholder virkeligheden af det sanselige objekt, men absorberer det fortvivlende fravær af den transcendentale fader (og så den opstegne søn) ved kun at blive objektet (nur [déjà]) for en 'følelse'. I sin form og sin funktion foregriber analogien allerede rollen som denne bestemte analogi kommer til at spille her - passage og forvandling fra et sæt af relationer til et andet der fastholder splittelsen og foregriber dens fjernelse.

Vor- i Hegels logik arbejder både på at skabe splittelsen og på at foregribe dens fjernelse. Så den »endelige splittelse» mellem tilstedeværelse og repræsentation (relation til faderen og relation til moderen) er i sidste ende selv baseret på logikken af Vor-, proe- eller før-i fornuftige intuitioner så vel som tanker og, endeligt, i selve idéen, det absolutte. Vorstellung involverer derfor både en relation til det fornuftige og en relation til tanker, to relationer der karakteriseres ved deres gåen fremad, gåen foran eller gåen forud for

27. "»Dets forsoning er derfor i dets hjerte, men alligevel splittet (noch entzweit) med dets bevidsthed og dets aktualitet alligevel brudt (noch gebrochen)« (248a/222a). 
hinanden - i forventning. Indledningen til Encyklopaedien begynder med en betragtning over vanskeligheden ved at lave antagelige begyndelser indenfor filosofien:

»Vanskeligheden af at lave en begyndelse opstår øjeblikkeligt, fordi en begyndelse idet den er ojeblikkelig, foretager en præ-supposition [Voraussetzung] eller rettere selv er netop det. ${ }^{28}$

Filosofi kan ikke forudsætte sine Objekter (Gegenstände) som øjeblikkeligt givne i repræsentation (Vorstellung), ligesom andre videnskaber kan, for filosofien er videnskaben af sådanne tanker af hvilke filosofiens præsuppositioner vil blive til Sandheden. Så filosofiens begyndelse er allerede dets objekt. Filosofien skal blive til sandheden af dets egen præsupposition. Denne logiks temporale cirkularitet bliver forstærket i "Vorbegriff» ('Præliminær konception' eller 'Forudseenhed'), hvor han skriver at alle Vorbegriffe »er bestemmelser der er hentet fra og efter bedømmelsen af det hele. ${ }^{29}$

\section{Vorbegriff}

Logikkens $^{30}$ egen begyndelse er mindre paradoksalt klar omkring punktet præsuppositioner: »Hvad logik er, kan ikke bestemmes på forhånd; dette kendskab til hvad det er, opstår snarere først som det endelige resultat og fuldendelsen af hele fremstillingen. ${ }^{31}$ Der er derfor ikke megen forvirring og uenighed omkring Hegels indledende begreb, Væren, blandt de sekundære kilder. Willem deVries er eksemplarisk i sit løfte og i sin endelige undladelse af at opfylde det: „Dog, som vi vil se, ved [Hegel] nøjagtigt hvor han skal begynde: Væren. ${ }^{32} \mathrm{Vi}$ ville blive tilgivet accepten af dette »som vi vil se» (måske den mest almindelige vending i alle kommentarer til Logikken) som

28. Hegel: Werke, bd. 8, Frankfurt/M 1970, p.41.

29. Werke, bd. 8, p.67. Dette foranlediger Derridas indskud om fortællingen af Hegelianske processer i hvilket han konkluderer: »Den encyklopædiske version af Logikken (cirkulær pædagogik/rundbordspædagogik for den studerende) fortæller sig selv i futurum perfectum" (Glas 22a/15a). Et stort antal af Hegel-fortolkninger følger utvivlsomt også denne praksis. I Glas er der ingen forudsætninger; indskuddene spiller imidlertid en ikke ulig, men dog fortrængt rolle.

30. Med Glas befinder vi os mere eller mindre mellem Fanomenologien og Logikken hvis vi husker på at dette 'mellem' også er hovedproblematikken i så vel de andre tidlige tekster som i de senere tekster, og at det faktisk er umuligt at lokalisere det som sådan. Så passagen mellem det næstsidste og det sidste kapitel i Fænomenologien foregriber passagen fra Fanomenologien til Logikken osv.

31. Hegel: Werke, bd. 5, Frankfurt a.M. 1969, p.35.

32. Willem deVries: »Hegel's Logic and Philosophy of Mind, in Robert C. Solomon og Kathleen M. Higgins (red.): The Age of German Idealism, London 1993, p.236. 
en betegnelse for en eller anden tilfredsstillende redegørelse for Hegels beslutning, men to sider senere læser vi: „Hvorfor er det sådan? Hvad gør 'væren' til det korrekte udtryk for logikkens udgangspunkt? Her møder vi en generel vanskelighed ved Hegels logik: De begrebsbetegnelser han vælger, virker ofte mindre end uimodståelige. At den simple, umiddelbare almindelighed med hvilken logikken begynder skulle kaldes 'tilværelse,' er faktisk mere intuitivt end mange af hans andre valg« (loc.cit. p.238). Og sådan fortsætter han. Denne forklaring af et Hegeliansk valg igennem 'intuition' kan måske virke pervers, men her er alle kommentarer om logikkens begyndelse i vildrede - selv de bedste, som inkluderer deVries' kommentarer. Hvorfor volder dette valg så mange vanskeligheder? Hegel var allerede begyndt med at vise os at logikkens eneste gyldige Objekt (Gegenstand) var logikken (som tager tænkningen i sig selv som sit Objekt). Han skriver,

»Men hvis man ikke kan foretage nogen præsupposition, og begyndelsen selv kan forstås umiddelbart, så er dens eneste bestemmelse at den skal være begyndelsen på logikken, på tænkningen som sådan. Alt hvad der er tilstedeværende, er udelukkende beslutningen, hvilket også kan betragtes som arbitrært, om at vi agter at betragte tænkningen som sådan. $\|^{33}$

Til at begynde med kunne den logiske kategori ikke have været Begrebet selv da det skal være resultatet. Sa Hegel begynder med en kategori der i den filosofiske arv betegner det absolut modsatte af begrebslighed, kategorien af Væren. Kategorien af Væren er begrebet om hvad der ikke er et begreb; derfor den direkte passage til begrebet Intet. Fra tanken om hvad der ikke er en tanke, kommer vi til tanken om intet (og ingen tanke). Det tredje udtryk, udtrykket som således reagerer på filosofiens behov, er Tilblivelse. Det er ikke (så vidt jeg ved) tilblivelse i den betydning det ofte bliver tillagt af kommentarer om Logikken, dvs. Heraklitansk tilbliven. ${ }^{34}$ Begrebet om Væren bliver rettere begrebet om Intet fordi Væren ikke er et Begreb. Tilblivelse er betegnelsen for passagen, splittelsen, spaltningen, behovet for filosofi, og det går forud for væren som dets erstatning eller tilføjelse. Hvad dette betyder, er at begrebet om tilblivelse i Hegel, hvis det for eksempel fortolkes som en form for kinetisk mediation, igennem hvilken noget (en væren) bliver til intet på den måde jeg bliver søvnig efter et stykke tid, så forbliver Hegel sår-

33. Werke, bd. 5, p.68.

34. Hegel kommenterer den Eleatiske skoles opfattelse af Væren og Heraklitus' Tilbliven i Logikken fra Encyklopadien, og bortset fra denne formelle mimesis af filosofiens tidlige udvikling skelner han bestemt sin egen brug af kategorierne fra deres (Werke, bd. 8, p.57). 
bar over for Kierkegaards anklage ifølge hvilken ordet 'repetition' stikker Hegels ide om 'mediation' med en 'trumf.' Dette er Kierkegaard under det ironiske pseudonym Constantin Constantius:

»Mediation er et udenlandsk Ord, Gjentagelse er et godt dansk Ord, og jeg gratulerer det danske Sprog til en philosophisk Terminus [Her fortsætter Kierkegaard med at lære filosofi at tale dansk] . . . Gjentagelsens Dialektik er let; thi det, der gjentages, har været, ellers kunde det ikke gjentages, men netop det, at det har været, gjør Gjentagelsen til det Nye. $\ll^{35}$

Traditionen ville altid have ønsket at ophæve repetition (som mekanisering eller som skrivemåde, Klang modsat Sprache). Men med idéen om omskiftning (som i gentagelighed), som forekommer mere tydeligt i Hegels Logik end idéen om kinetisk overgang gør, burde der måske ikke have været et behov for at etablere noget som Ånd eller Bevidsthed ud over det betingede mekaniske univers fordi effekterne af at have en uafhængig ånd ville have været effekterne af repetition. Tilblivelse sker næsten med det samme mellem 'ikke endnu' og 'allerede' i dets ophævelse af 'nuet.' Denne ophævelse ville ikke dreje sig om tidens gang, men mere om forkortelsen af seglet som signaturens begivenhed ifølge hvilken jeg allerede er død, allerede intet.

\section{Vorstellung}

Så begrebet som sådan (ultimativt: det absolutte) er formet ved dets begyndelse (strengt taget før dets begyndelse) og i dets mulighed som en relation til intet (relationen til Væren som en forstillelse), relationen til det uantagelige, men fundamentale 'ikke der.' Sagen bringer os tilbage til Glas idet den fokuserer på rollen af forudgående Vorstellung (repræsentation) som passagen selv, eller som jeg lige har antydet, tilblivelsen af Hegels begyndelse, men nu formet efter en arvet figurering af den Treenige familie. Vorstellung som medium og passage ville altid have været en begrænsning af absolut fuldendelse, hvis det ikke havde været muligt at underordne den relation til intet der er forudsat af passagen fra begrebet om Væren til begrebet om

35. Gjentagelsen, Skrifter, red. Niels Jørgen Cappelørn et al., bd. 4, København 1997, p.25. Se John Llewelyns artikel for mere omkring den måde fragmenterne af Kierkegaard er til stede hele vejen gennem Glas. Og se Samuel Webers "'As Though the End of the World had Come and Gone . . .: Critical Theory and the Task of Reading, Or: Allemal ist nicht immergleich, "New German Critique 81 (2000), pp. 83-105, for en fremragende læsning af Kierkegaard om gentagelsen, og som læser 'Adorno om Kierkegaard' idet den også læser Adorno gennem Kierkegaard - Kierkegaard som et magtfuldt pseudonym for det 'ikkeidentiske.' Eller, som Weber konkluderer, omvendt (p.105). 
Intet, under noget bestemt. Selvfølgelig er det altid muligt at ordne relationen til intet under en eller anden bestemmelse. Det viser sig at dette er muligheden for bestemmelse i sig selv. ${ }^{36}$ Dog modarbejder logikken i Vorstellung bestandigt sin underordning. Vorstellung i sine tre stadier: Erinnerung (erindring), Einbildungskraft (fantasi - og her foregriber vi fantasibilledet) og Gedächtnis (hukommelse), internaliserer i stigende grad sit objekt. Et billede af objektet er skilt fra dets umiddelbare intuition eller opfattelse (f.eks. kan jeg genkende et objekt ved gentagende gange at have stødt på det). Dette billede kan så forbindes med/til et symbol eller billede (dvs. et tegn) i fantasien. Hukommelsen (Gedächtnis) gentager så processen af Erinnerung med tegnet (idet den internaliserer hukommelse). På den måde, fortæller Hegel, kan objektet være mit. Processen skaber passagen til begrebsdannelsen som det der internaliserer det ydre i en fuldendelse. ${ }^{37}$

Komplikation: i Logikken er den præsuppositionsløse begyndelse allerede selv kun Vorstellung. Den Vorstellung som internaliserer sit objekt det der står over og imod det, dets modscetning (Gegensatz) - må derfor begynde med en tom repræsentation af (eller tegn på) intet. Dette er den eneste måde at nå til konceptionen af tænkningen selv; tænkningen uafhængig af bestemte tanker, der er forudsat af konceptionen. En Vorstellung der allerede var bestemt, ville ikke være en Vorstellung af Vorstellung i sig selv. Dette er stadig kun et enkelt aspekt af et problem i vestlig filosofi, som Hegel retfærdigt er berømt for at bringe for dagen, paradokset af selv-refleksive begreber nedarvede fra middelalderens logik i det følgende spørgsmål: er begrebet 'begreb' et begreb? Idet et begreb henviser til sig selv, henviser det ikke til hvad alle andre begreber henviser til, et objekt; begrebet 'begreb' henviser snarere til en indtil videre ugengældt henvisning, eller et henvisende potentiale (den før-placerede, pro-positional, tilføjelse). Ligeledes kan repræsentation ikke laves om til et objekt og internaliseres som en repræsentation uden at reducere den til bestemte repræsentationer, hvilket betyder at repræsentation altid overgår sine egne grænser og altid dukker op igen udenfor repræsentations område som det der forbliver ubestemt. Ud fra denne læsning lyder logikken som om den måske allerede er dekonstruktion.

Hele Logikken er påvirket af denne komplikation som måske er realiseret mest klart i anden del, »Essensens Doktrin, « hvor Hegel under »Væsentlighe-

36. Derrida har en lignende pointe i »Différance« in Margins of Philosophy. Brighton 1982, pp.1-27, hvor han viser at det altid er muligt at udviske, reducere, ignorere eller forbigå i stilhed, hans stavefejls tavse brud, $a$-et.

37. Encyklopcedien, Werke, bd. 10, Frankfurt a.M. 1970, \$\$451-64. I biologien, for eksempel, opnår processen en undfangelse (conception) via parring (Glas 138a/120a). Hvis Hegel vælger at skelne naturlige processer fra åndelige processer, så svarer processerne selv nøjagtigt, selvom det er netop den splittelse der interesserer ham. 
der af Refleksionsbestemmelser« vælger at sætte Identiteten op imod Forskellen. Ifølge vedholdenheden af et mønster der allerede er etableret, nedarvet fra traditionen som den næsten absolutte religion, bliver en bestemt Identitet påkaldt for at føre krig imod forskellen og modsætningen i forsoningens navn. Forskellen må bestemmes som Identitetens modsætning (simpelthen modsat) for at bringe det sammen med identiteten selv (Absolut forskel som identitetens modsætning eller, hvilket er det samme, en anden identitet). Men forskellen i sig selv (grundlaget for modsætningen i sig selv, i dets usynlige [fraværende] tilstedeværelse imellem udtrykkene i rækken: spaltning, adsplittelse, splittelse, adskillelse, opdeling, brud, krænkelse, opløsning, deling, osv.) forbliver. ${ }^{38}$ Hegels beslutning om at sætte forskellen op imod identiteten involverer derfor tre stadier (momenter eller magter) af 'overvindelse.'

Logikken identificerer tre typer (vi kunne kalde dem klasser) af forskel på følgende vis: der Unterschied (forskel som forskel eller absolut forskel); die Verschiedenheit (forskel som forskellighed); og der Gegensatz (forskel som modsætning). Hver af disse typer er forskellige fra de andre. Hver har sin egen lov som kendetegner den (hver forskel har sin egen identitet) således at der er en forskellighed af forskelle. Men igennem en logik der ligner den i det tilføjelige $V o r$ - det vil sige, igennem logikken i Logikken som vi fulgte den - skulle den anden type (forskellighed) på en eller anden måde gå forud for den første (forskel) og overgå den tredje (modsætning) som derfor vil have været ude af stand til helt at overvinde sig (selv). Uden Identitetens "falden fra hinanden inden i sig selv ind i forskellighed « ville den absolutte forskel ("som enheden af sig selv og identitet«) ikke have været tænkelig som en forskel overhovedet. Absolut forskel har sin anden i sig selv og har derfor ingen relation til noget uden for sig selv: »det er ikke overgang til en anden, ikke en relation til en anden udenfor det selv: det har sin anden, identitet, inden i sig selv.«Die Verschiedenheit, på den anden side, »udgør forskelligheden som sådan af refleksion. ${ }^{39}$ I den forstand er forskellen som forskellighed

38. En konstant modus operandi, som er at finde i hele Derridas forfatterskab, træder frem i denne måde, hvorpå han fremdrager den paradoksale logik bag at skabe begreber der ikke er begreber - hvis begrebet er bestemt som bestemmelse (hvilket det er nødt til at være). Bortset fra den notoriske dekonstruktion af tegnet, den »dårligt benævnte ting « der unddrager sig filosofiens stiftende spørgsmål (De la grammatologie, Paris 1967, p.31), og det berømte retoriske spørgsmål i begyndelsen af "Signature Event Context« omkring kommunikation, ville vi gøre opmærksom på en tekst der på mange måder er meget tæt på Glas, "Parergon" som sænker Kants 3. kritik ned i "afgrunden" på basis af dens aktive tilflugt, analogien (The Truth in Painting, Chicago 1987, p.36). Det der er afgørende hver gang, er at tilflugten, ressourcen, kraften eller magten af disse ikke-begreber forbliver. Altså bør der i deres potentiale være noget der ikke kan bestemmes, noget der forbliver ufuldstændigt, og som derfor ikke under nogen omstændigheder kan nærme sig en afslutning. Risikoen er dermed at der i tænkningens eventyr måske altid overhovedet ingen tænkning er.

39. Werke, bd. 6, p.48. 
sat op imod forskellen som forskel i sig selv, og som Derrida skriver, er modsætningen »un gond," et hængsel, i Logikken (Glas 189a/168a). Det er hængslet der forbinder identitet med forskel, der forener lighed med ulighed mens det samtidig holder dem fra hinanden. Forskellen som forskellighed antyder foreningen af to modsatte prædikater - lighed og ulighed - og Hegel udvikler dette med hensyn til loven ifølge hvilken to ting ikke kan være fuldstændig ens (dvs. identiske) så selv hvis de er ens (f.eks. »fordi de er ting eller kun to, uden yderligere begrænsning, for hver er en ting og en enhed, ikke mindre end den anden«), er de også forskellige »men det er de gennem Annahme, ${ }^{40}$ det vil sige, ifølge 'antagelsen' eller Voraussetzung (hvilket er hvad Annahme er for Hegel - A. V. Miller oversætter det som ex hypothesi) af loven om forskellighed. Så loven om forskellighed er en følge af Voraussetzung ifølge hvilken to ting aldrig kan være identiske trods mulighederne for deres lighed (eller klassifikation). Forskellen på lighed og ulighed (gleich und ungleich) må forestilles sammen (zugleich), øjeblikkeligt, på samme tid. Så Hegels berømte (eller foragtede) gendrivelse af den klassiske lov om ikke-modsigelse involverer en a priori tilføjelse af hvad han kalder die Insofern, for så vidt, som holder das Zugleich (foreningen) af begge prædikater fra hinanden, dvs., når det kan siges om to ting at de er ens for så vidt som de ikke er forskellige, når de i en eller anden henseende er ens, men ikke nødvendigvis i andre. Så hvis modsætningen mellem forskellen og forskelligheden er et hængsel for den større Logik (uden det ville der ikke være nogen overgang), så er forskellighed i sig selv allerede et hængsel mellem identiteten og forskellen. Hængslet hænger Logikken på et andet hængsel. Forskelligheden som en ligegyldig forskel (indifferent difference), udvendigheden per se sat op imod intet, antyder et forhold mellem identiteten og forskellen som er noget andet end modsætning og minder os temmelig elegant om Genets l'un-l'autre fra det som bliver tilbage af en Rembrandt (ce qui est resté d'un Rembrandt), ifølge hvilket en utallig mangfoldighed af individualiteter er skabt både i uafhjælpelig modsætning og dog skjuler ens identiteter, med andre ord (igen): loven om repetition. Denne logik er udviklet troligt i Glas, men med hensyn til Hegels bestemmelse af seksuel forskel er den baseret på den homoseksuelle model af den Treenige familie: »Denne bestemmelse af seksuel forskel som modsætning, som modsætning engageret i hele processen af modsætning (Entgegensetzung) i almindelighed, af objektivitet (Gegenständlichkeit), og af repræsentation (Vorstellen), opretholder en historisk og systematisk essentiel forbindelse med den Ubesmittede Undfangelse: hvis ikke med dogmet angående Marias fødsel, så i det mindste med dets præmis eller dets konklusion, moderens jomfrue-

40. Werke, bd. 6, p.54. 
lighed «(250a/223a). Den potentielle Fader klarer sig uden Moderen; Moderen klarer sig (kommer og undfanger) uden den egentlige fader.

\section{Foregribelser}

"Filosofien ... er sin egen tid undfanget $i$ tanker $\aleph^{41}$

Så hvad er det der gør familien som sådan uantagelig i systemet? I hvert øjeblik forbliver en modsætning (idet den deler selve tiden) og bestemmer sig selv som en foregribende Vorstellung. "Det essentielle prædikat i denne repræsentation er yderligheden af hvad der viser sig eller bekendtgør sig selv der.«(246a/219a) De strukturelle og temporale dimensioner af Vorstellung (og alt andet der er behersket af og derfor behersker Aufhebung som deler sig i to i forsoningens navn) påtvinger en striktur og samtidig en modstriktur da de forbinder 'det kommende' med 'allerede væk' af her, nu af nærværende perception. Det er denne ikke-synlige effekt af relationen til 'ikke der' som forbliver uantagelig fordi den ikke kan opfattes, internaliseres eller laves til et objekt af erfaring overhovedet - undtagen som repræsentation og så som foregribelse som ikke kan beregnes. Den kan ikke beherskes. Så denne fundamentale strukturelle bestanddel af systemet undgår al systematisering mens den gør det muligt. På dette punkt viser filosofisk påvisning sig at være utilstrækkelig. Denne »knap eksisterende grænse der overskrides så snart den er sat, « der viser sig mellem absolut religion og $S a$, åbner systemet for en kraft der er uudtømmelig, men som kun kan afsløres med hensyn til hvad der mangler, med hensyn til fiaskoen: "Se denne grænse beskriver en absolut familiescene. På en elliptisk måde. Denne grænse er selve ellipserne i familiecirklen: cirklen indskriver sig i en ellipse i hvilken det der mangler (ellipse), er en følge af at det ikke lykkedes familien at centrere sig« (246a/ 220a). Hjertet er der bare ikke. Og her bliver vi igen mindet om at der foregår noget hen over siden som genlyder eller mere eller mindre, gentager $\mathrm{i}$ en eller anden form (parodi, satire, sammentræf?) det andet tilfælde. Jeg citerer en tilsyneladende affærdigende Georges Bataille:

»Det interessante aspekt ved Genets værk ligger ikke i dets poetiske magt, men i den lære vi kan lære af dets svaghed. [ . . .] Der er, jeg ved ikke hvad, en skrøbelig, kold, løs kvalitet i Genets værk som ikke nødvendigvis forhindrer os i at beundre det, men som får os til at tøve med at være enige med ham. $\ll^{42}$

41. Hegel: Grundlinien der Philosophie des Rechts, Werke, bd. 7, Frankfurt a.M. 1970, p.26. 
Og to indføjelser: »jeg ved ikke hvad. Kritik af jeg ved ikke hvad. Jeg ved intet om fr« og »hjertet er virkelig ikke til stede« (246b/220b). »Jeg ved ikke hvad« i Genets fiasko kan bekræftes som kraften af $f r$ (ligesom den af $g l$ ) i dets gåen forud for sig selv som et ubestemt potentielt udtryk. Dele af den højre spalte fremhæver Genets kritikeres manglende evne til at imødekomme eller indrømme kraften af fiaskoen. ${ }^{43} \mathrm{I}$ de indledende stadier af denne spalte (vi vil ikke sige begyndelsen) forbereder Glas sig til en læsning af Genet og skaber fortrin for de ubestemmelige og derfor »næsten ubeskrivelige « reste(r) (den je ne sais quoi de fr) af Genets tekst. I fraværet af titler, fodnoter, principper, postulater eller aksiomer dukker der her noget op der ligner en "nøgle« - i en tilsyneladende negativ form - som angiver nomenklaturen og klassifikationen og som bruges af kritikere som Jean-Paul Sartre til at "åbne« Genet; dette er dobbelt ironi da Sartres rolle i befrielsen af det kriminelle nu kan ses at have fanget forfatteren: "At prøve endnu en gang at arrestere eller standse den [udviklingen af det ukendte, dets glas], som i 1952 hvor befrielsens ontofænomenologist ved udgangen fra fængslet [. . .] insisterede på at aflevere 'nøglerne' til manden-og-det-samlede-værk til dig, deres endelige psykoanalytiske-eksistentielle betydning, lige i din hånd, til et sikkert sted«(36-37b/28-29b). Ellipsen betegner en indføjelse som opdeler dette citat som det fremtræder i Glas, og som omfatter et forlænget citat fra Sartre der gør en nødvendig fremgangsmåde til at forstå Genets værker, gældende: "»Hvis vi vil forstå hvad han er i dag og hvad han skriver, må vi gå tilbage til dette oprindelige valg [dvs., at være tyven] og prøve at give en fænomenologisk beskrivelse af det.«" ${ }^{44}$ Hvis, som jeg lige har påstået, noget der ligner en nøgle dukker op i Derridas tekst, bliver det tilbage at spørge - i hvilken forstand ville dette noget der ligner en nøgle, være forskellig fra den der tilbydes af Sartre? Den rolle som nøglen, clef, allerede spiller i Genet, som tilsyneladende gør Sartre blind for (og binder ham til) den seksuelle figur af nøglen - »en universel nøgle der glider ind i alle betegnende lakuner» (37b/29b), fanger den som tror at han har nøglen inden i den tekst som han påstår at åbne med kategorier udenfor teksten. Det der dukker op i Glas, har mere at gøre med en måde at blive ulæselig på, en klokkes ringen og en bestemt betydnings henfald og hendøen, dets fiasko. Men ligesom vi finder overensstemmelse igennem hele Hegel spalten (men denne titel burde selv

42. "L'intérêt de l'oeuvre de Jean Genet ne vient pas de sa force poétique, mais de l'enseignement qui résulte de ses faiblesses. [...] Il y a dans les écrits de Genet je ne sais quoi de frêle, de froid, de friable, qui n'arrête pas forcément l'admiration mais qui suspend l'accord'" (Glas 246b/220b).

43. F.eks. Glas $35-39 \mathrm{~b} / 27-31 \mathrm{~b}$, der sammen med afsnittene om eksemplifikation, retorik, og den eksemplariske Gud (36-38a/28-30a), fængsler.

44. Citeret i Glas 36b/28b. 
blive gjort ulæselig med hensyn til hvad som helst den kan have bestemt), så er dette heller ikke nogen ligefrem ulæselighed, tilfældigt uklar eller kryptisk. Ifølge Glas er det en ulæselighed »uden hvilken der ikke ville være nogen tekst« $(41 \mathrm{~b} / 33 \mathrm{~b})$, en ulæselighed der er mulighedens betingelse for den læselige tekst, uadskillelig fra den læselige tekst, dens ulæselighed, læsningens ulæselige betingelser. Det ville være muligt at rekonstruere en kæde: rækken af $g l$ - grafemer i løbet af de indledende sider af Tyvens Dagbog, blomsten som stedet for »nulbetydning, « ulæseligheden af egennavnet, systemet af nomineringer, anbringelsen af signaturer i stedet for manglende objekter, de rekonstruerede fragmenter af en frigivet rest, dødens segl som déjà. Og igen som med Hegel ville nøglen være en bestemt paradoksal frihed - som fængsler ved at befri, eller omvendt.

Hvordan ville man læse (op)delingen mellem de to spalter? Mulighederne er konstant givne af uantageligheden (filosofiens passage eller behov) som vi kan spore i Hegel og i det ulæselige spor i Genet. Det ville være et spørgsmål om at bekræfte overensstemmelsens fiasko som den absolutte overensstemmelses umulighed (ikke der) og som muligheden for overensstemmelse som sådan i hvad der giver sig selv til bestemmelse - ingen relation. Glas giver et eksempel på reglen for exceptionelle regler. Ved på forskellige måder at inkorporere den andens signatur skaber og udstiller Glas reglerne for en form for skrivemåde der, ifølge Derrida, "må udsætte sig for risikoen af en formel oplevelse.« Imperativet gælder hvis forfatteren ønsker at tage udfaldet (og dets segl, Hgl, JG) i betragtning. Hegel spalten (respektfuld, tålmodig påvisning, på betydningens side) eller kun seglet $\mathrm{Hgl}$ og Genet spalten (uærbødig, revolutionær afbrydelse ved siden af betydningerne, de små, under-syntaktiske fragmenter), Genets je m'éc-, kan hver læses som pålægningen af regler der gælder for dem selv - for det påbud der går forud for sig selv. Til at begynde med fungerer passagen mellem betydning og syntaks ifølge en striktur eller binding af adskillelse som kun læsning vil kunne løse. Den respekt og beundring man kan føle for Hegel, og som påvises i $\mathrm{Hgl}$, viser en ekstrem troskab mod hvad der viser sig at være en ekstremt dekonstruerlig tekst - så dekonstruerlig at den næsten er udekonstruerlig, den er næsten allerede (men ikke endnu) dekonstruktion. Passagen fra det absolutte mellem 'allerede' og 'ikke endnu' i Hegels tekst til dekonstruktionens 'ikke der' ville måske være dekonstruktion i sig selv, gaven af ingen relation. Hvis noget forbliver.

Oversat fra engelsk af Henriette Backs. Redigeret af Jakob Lund og redaktionen. 
